\title{
Tanggung Jawab Indonesia sebagai Negara Transit bagi Pengungsi Anak Berdasarkan Hukum Internasional
}

\author{
M. Riadhussyah \\ Mahasiswa Program Studi Magister Ilmu Hukum \\ Fakultas Hukum, Universitas Brawijaya \\ Jln. MT. Haryono No. 169 Malang Jawa Timur Indonesia \\ mriadhussyah@gmail.com
}

\begin{abstract}
This research examines: first, the responsibility of Indonesia as a transiting country for the child refugees based upon the international law. Second, setting the responsibility of Indonesia for the child refugees according to national law in the future. It is a normative legal research with the method of statute approach, conceptual approach, and comparative approach. The result of the research concluded that: first, Indonesia normatively has a responsibility as a transiting country though not as the party in the Convention of Refugees 1951 and protocol 1967, but bound by the convention of children rights mentioning to be responsible for giving protection to the children as the refugees. It also concluded that the custom of international law and the general law principle that is jus cogens that obliges the state to protect the human rights as a form of protection towards humanity. Second, the form of responsibility of Indonesia for the child refugees in the regulation of national law in future is that Indonesia must ratify the Convention of the Refugee 1951 with its protocol and regulate the derivative regulations of the convention.
\end{abstract}

Keywords: State responsibility, transiting country, child refugees

\begin{abstract}
Abstrak
Penelitian ini mengkaji: pertama, tanggung jawab Indonesia sebagai negara transit bagi pengungsi anak berdasarkan hukum internasional. Kedua, pengaturan tanggung jawab Indonesia bagi pengungsi anak menurut hukum nasional di masa yang akan datang. Metode penelitian menggunakan penelitian hukum normatif, sedangkan metode pendekatan yaitu pendekatan perundang-undangan (statute approach), pendekatan konseptual (conceptual approach), dan pendekatan perbandingan (comparative approach). Penelitian ini menyimpulkan: pertama, Indonesia mempunyai tanggung jawab secara normatif sebagai negara transit walaupun bukan menjadi negara pihak dalam konvensi Pengungsi 1951 dan protokol 1967, tetapi Indonesia terikat dalam konvensi hak-hak anak yang menyebutkan wajib memberikan perlindungan kepada anak yang menjadi pengungsi. Serta kebiasaan hukum internasioal dan prinsip hukum umum yaitu jus cogens mewajibkan negara untuk melindungi hak-hak asasi manusia sebagai bentuk perlindungan terhadap kemanusiaan. Kedua, bentuk tanggung jawab Indonesia bagi pengungsi anak dalam pengaturan hukum nasional di masa yang akan datang adalah Indonesia harus meratifikasi Konvensi pengungsi 1951 beserta protokolnya, dan membuat peraturan perundang-undangan turunan dari konvensi tersebut.
\end{abstract}

Kata kunci: Tanggung jawab negara, negara transit, pengungsi anak 


\section{Pendahuluan}

Setelah enam belas tahun Indonesia meratifikasi Konvensi Hak-hak Anak, tepatnya pada 25 Agustus 1990 melalui Keputusan Presiden Republik Indonesia Nomor 36 Tahun 1990 (Lembaran Negara tahun 1990 Nomor 57), Indonesia telah mempunyai kebijakan dan peraturan perundang-undangan tentang perlindungan anak yang berorientasi pada Konvensi Hak-hak Anak. Pada 22 Oktober 2002, Indonesia menetapkan Undang-Undang Nomor 23 Tahun 2002 tentang Perlindungan Anak (Lembaran Negara Tahun 2002 Nomor 109, tambahan Lembaran Negara Nomor 4235, yang selanjutnya disebut undang-undang perlindungan anak) yang berorientasi pada hak-hak anak seperti yang tertuang dalam Konvensi Hak-hak Anak yang selanjutnya diubah menjadi Undang-Undang Nomor 35 Tahun 2014 tentang Perubahan Atas Undang-Undang Nomor 23 Tahun 2002 tentang Perlindungan Anak (Lembaran Negara Republik Indonesia Tahun 2014 Nomor 297, tambahan Lembaran Negara Republik Indonesia Nomor 5606).

Segenap komponen yang dimiliki negara harus dijalankan secara maksimal untuk memantapkan tujuan pengembangan calon penerus kehidupan berbangsa dan bernegara di hari kemudian dengan menjalankan fungsi pengaturan dan pelaksanaan dari aturan tersebut. Namun, situasi dan kondisi anak saat ini, mencerminkan adanya penyalahgunaan anak (abuse), eksploitatif ${ }^{1}$, diskriminatif dan mengalami berbagai tindakan kekerasan yang membahayakan perkembangan jasmani, rohani, dan sosial anak².

Perkembangan perlindungan anak tidak hanya melingkupi anak dari Warga Negara Indonesia, melainkan seluruh anak yang ada di Indonesia. Hal ini mengingat adanya warga negara asing yang datang ke Indonesia membawa anaknya, sehingga hal itu pun menjadi salah satu fokus dalam perlindungan anak.

${ }^{1}$ Eksploitasi terhadap anak yaitu "because child trafficking is lucrative and often linked with criminal activity and corruption, it is hard to estimate how many children suffer, but trafficking and exploitation is an increasing risk to children around the world. Often they are trafficked for commercial sexual exploitation, like prostitution, or for labor such as domestic servitude, agricultural work, factory work, mining, or child soldiering. There are 215 million children engaged in child labor, with 115 million of those children in hazardous work. Sometimes sold by a family member or an acquaintance, sometimes lured by false promises of education and a "better" life — the reality is that these trafficked and exploited children are held in slave-like conditions without enough food, shelter, or clothing and often severely abused and cut off from all contact with their families". Save the Children, Protecting Children from Exploitation, www.savethechildren.org, diakses tanggal 10 April 2016.

${ }^{2}$ Karnia Septia, "Menteri Yohana: Indonesia Darurat Kekerasan terhadap Anak", www.kompas.com, diakses tanggal 16 Desember 2015. 
Melihat trend perkembangan masyarakat internasional mengalami perubahan, pada dewasa ini memiliki ciri baru yaitu pergerakan yang intens dan mobilitas kehidupan yang tinggi ${ }^{3}$. Mobilitas tersebut mengakibatkan perubahan pada tingkat kejahatan yang ikut berkembang mengikuti perkembangan mobilitas dan intensitas pergerakan masyarakat tersebut, sehingga kejahatan tersebut bersifat transnasional. ${ }^{4}$ Untuk itu, diperlukan upaya-upaya yang akan memberikan perlindungan khusus kepada anak-anak Indonesia yang berada dalam keadaan sulit yaitu dengan adanya eksploitasi anak dan pelanggaran hak-hak anak, ke dalam suatu program nasional bagi anak Indonesia sebagai tindak lanjut Sidang Umum PBB untuk anak yang melahirkan deklarasi " $A$ World Fit For Children ".

Selanjutnya dinamika perkembangan masyarakat internasional telah mengalami perkembangan yang pesat, hal ini dapat terlihat dengan berkembangnya ilmu pengetahuan dan teknologi, sehingga mengakibatkan teknologi transportasi menjadi salah satu yang sangat berguna untuk perpindahan (migrasi) penduduk dari satu negara ke negara lain.

Akhir-akhir ini pemberitaan mengenai mobilitas pengungsi kian marak. Kedatangan pengungsi Rohingya yang berasal dari Myanmar merupakan suatu contoh tentang pemahaman keterkaitan hak-hak yang melekat pada pengungsi secara universal tersebut yang secara khusus pada pengungsi anak yang ikut terdampar pada wilayah Indonesia, karena hak-hak yang melekat pada seorang yang dewasa dan anak merupakan hal yang berbeda. ${ }^{5}$

Pengungsi biasanya berasal dari etnis minoritas di negaranya yang tidak selalu mendapatkan perlakuan yang baik di wilayah negara yang didudukinya. Kedatangan pengungsi pada suatu negara biasanya tidak sendiri, mereka membawa sanak keluarga termasuk anak, sehingga pengungsi anak-anak akibat

${ }^{3}$ Muhammad Alif Goenawan, 2015 soal Mobilitas, Medsos, Big data dan Cloud, www.detik.com, diakses tanggal 21 Desember 2015.

${ }^{4}$ Wagiman, Hukum Pengungsi Internasional, Sinar Grafika, Jakarta, 2012, hlm. 48.

${ }^{5}$ Lihat dalam Makarim Wibisono, "Dilema Rohingya", Majalah DETIK edisi 1-7 Juni 2015), Jakarta, Detik, 2015, "perlakuan sehari-hari yang diskriminatif dari pemerintah Myanmar dan masyarakat Buddha di Rakhine. Partai Nasional Pembangunan Rakhine telah dibentuk di wilayah barat Myanmar, yang senantiasa berkampanye anti-Rohingya. Kebetulan, semua orang Rohingya beragama Islam dan dituduh sebagai imigran gelap asal Bangladesh. Sehingga, tidak mengherankan apabila UU Kewarganegaraan (Myanmar Citizen Act) telah diterima parlemen pada tahun 2011, yang menyatakan bahwa bangsa Myanmar terdiri atas 138 suku bangsa dan Rohingya tidak termasuk di dalamnya. Oleh karena itu, terdapat 800.000 penduduk Rohingya di Rakhine yang tidak memiliki kewarganegaraan Myanmar". 
konflik di negara asalnya memerlukan perhatian dan perlindungan yang sama seperti pengungsi dewasa. Hal ini mengingat kebutuhan khusus dan kerentanan mereka sehingga mereka harus pula menerima perlindungan dan bantuan khusus. ${ }^{6}$

Dalam keadaan darurat, pengungsi anak-anak mudah terpisah dari keluarganya. Maka, upaya registrasi dan penelusuran harus segera dilembagakan. Anak-anak yang terpisah menghadapi resiko yang lebih besar, karena mereka bisa saja direkrut untuk menjadi tentara atau dieksploitasi secara seksual.7 Pengungsi anak juga rentan menjadi korban dalam tindak kejahatan internasional, seperti human trafficking. ${ }^{8}$ Karena kebutuhan perkembangan normal dari anak yang sedang tumbuh, bahkan pengungsi anak yang tetap tinggal dengan keluarganya sangat menderita trauma dan gangguan akibat dari pelarian yang dilakukan. ${ }^{9}$

Adanya pembedaan dan perlakuan khusus yang harus diterima oleh anak dimana pun kondisinya, baik sebagai pengungsi pun ia harus menerima penghargaan hak tersebut.

Jumlah pengungsi anak yang tercatatkan dalam pada UNHCR tidaklah sedikit, hingga saat ini terdapat 2.507 Pengungsi anak dimana 798 di antaranya merupakan anak-anak tanpa pendamping ${ }^{10}$. Akan menjadi sangat miris dan menyedihkan apabila anak-anak tidak mendapatkan pelayanan sesuai denga kebutuhan dan perkembangannya hanya karena Indonesia bukan merupakan negara pihak dalam konvensi 1951 dan protokol 1976.

Meskipun Indonesia tidak meratifikasi konvensi Pengungsi 1951, akan tetapi Indonesia merupakan negara peserta konvensi hak-hak anak. Maka dalam hal perlindungan terhadap pengungsi anak, Indonesia harus mengacu pada konvensi hak-hak anak dalam memberikan perlindungan hukum terhadap pengungsi anak-anak yang ada di Indonesia. Maka dengan itu perlu diadakan pola pemahaman baru tentang perlindungan anak yang berbasis dari aturan-aturan yang berlaku secara universal, sehingga dapat dijadikan acuan awal dalam

${ }^{6}$ Fita Erdiana, "Perlindungan Hukum Bagi Pengungsi Akibat Konflik Bersenjata Di Republik Demokratik Kongo Menurut Hukum Pengungsi Internasional”, Surakarta, Tesis, Universitas Sebelas Maret, 2009, hlm 76.

${ }^{7} \mathrm{Ibid}, \mathrm{hlm} 77$.

${ }^{8}$ Save the Children, Children Refugee Crisis, www.savethechildren.org, diakses tanggal 10 April 2016.

${ }^{9}$ Fita Erdiana, Op. Cit., hlm. 75.

${ }^{10}$ Suaka, Refugees and Asylum Seekers in Indonesia, www.suaka.or.id, diakses pada tanggal 18 Maret 2016. 
melaksanakan perlindungan terhadap anak dalam rangka tanggung jawab negara bagi pengungsi anak yang ada di Indonesia.

\section{Rumusan Masalah}

Berdasarkan uraian di atas, permasalahan yang akan dikaji dalam penelitian ini adalah: pertama, apakah bentuk tanggung jawab Indonesia terhadap pengungsi anak menurut hukum internasional sebagai negara transit? Kedua, bagaimana seharusnya pengaturan tanggung jawab Indonesia bagi pengungsi anak menurut hukum nasional di masa yang akan datang?

\section{Tujuan Penelitian}

Adapun penelitian ini bertujuan untuk mengetahui dan menganalisis, pertama, bentuk tanggung jawab Indonesia terhadap pengungsi anak menurut hukum internasional sebagai negara transit. Kedua, pengaturan tanggung jawab Indonesia bagi pengungsi anak menurut hukum nasional di masa yang akan datang.

\section{Metode Penelitian}

Penelitian ini merupakan penelitian hukum normatif, yaitu penelitian yang dilakukan terhadap asas-asas hukum, kaedah-kaedah hukum dalam arti nilai (norm), peraturan hukum konkrit dan sistem hukum ${ }^{11}$, yang berhubungan dengan materi yang diteliti. Pendekatan penelitian yang digunakan meliputi: a. Pendekatan perundang-undangan (statute approach), yaitu dilakukan dengan menelaah undang-undang dan regulasi yang berkaitan dengan masalah yang dibahas, dalam metode pendekatan perundang-undangan perlu memahami hierarki dan asas-asas dalam peraturan perundang-undangan; ${ }^{12} \mathrm{~b}$. Pendekatan konseptual (conceptual approach), dilakukan dengan mengkaji pandangan/konsep

\footnotetext{
11 Sudikno Mertokusumo, Penemuan Hukum, Liberty, Yogyakarta, 2004, hlm. 29.

12 Peter Mahmud Marzuki, Penelitian Hukum, Prenanda Media Group, Jakarta, 2014, hlm. 136.
} 
para ahli yang berkenaan dengan masalah yang dibahas. Pendekatan ini dilakukan manakala aturan hukum tidak atau belum ada ${ }^{13}$ sehingga pandangan para ahli menjadi salah satu dasar dalam menguatkan pandangan peneliti; c. Pendekatan perbandingan (Comparative Approach), dilakukan dengan mengadakan perbandingan hukum. Perbandingan yang dimaksud adalah kegiatan untuk membandingkan hukum suatu negara lain atau hukum dari suatu waktu tertentu dengan hukum dari waktu lain. ${ }^{14}$ Perbandingan hukum sangat bermanfaat karena dengan membandingkan dalam terungkap latar belakang adanya ketentuan hukum tersebut sehingga dapat menjadi rekomendasi bagi penyusunan atau perubahan peraturan perundang-undangan yang sesuai dengan pembahasan peneliti. Filipina dipilih sebagai negara perbandingan karena merupakan negara ASEAN yang meratifikasi Konvensi pada 22 Juli 1981. Filipina sangat terbuka terhadap pengungsi, bahkan dalam laman resmi istana negara, Filipina dianggap sebagai tempat bagi pengungsi. ${ }^{15}$

Cara atau teknis pengumpulan bahan hukum yang digunakan adalah studi dokumentasi yakni dengan mencatat informasi dari bahan hukum yang berkaitan dengan yang akan diteliti, baik secara normatif maupun berupa ide atau gagasan. Pencatatan ini dilakukan secara selektif untuk mendukung dan melengkapi bahan hukum yang diperoleh dari sumber lain. Seluruh bahan hukum yang diperoleh dari penelitian kepustakaan selanjutnya akan dianalisis secara deskriptif-kualitatif dengan membangun argumen berdasarkan kepada logika berfikir deduktif.

13 Ibid.

${ }^{14}$ Ibid., hlm. 173

15Presidential Museum and Library, The Philipines as Haven for Refugee, www.malacanang.gov.ph diakses tanggal 10 April 2016. 


\section{Hasil Penelitian dan Pembahasan}

\section{Bentuk Tanggung Jawab Indonesia terhadap Pengungsi Anak Menurut Hukum Internasional Sebagai Negara Transit}

\section{Pengungsi Internasional dalam Hukum Internasional dan Hukum Hak Asasi Manusia}

Perlindungan hukum bagi seluruh masyarakat merupakan suatu tanggung jawab yang wajib dijalankan oleh negara, adapun salah satu hal yang menjadi perhatian utama dalam dengan memberikan jaminan terlindunginya akan Hak Asasi Manusia $(\mathrm{HAM})^{16}$. Di dalam negeri, masyarakat yang dilayani terhadap perlindungan HAM tidak hanya terdiri dari warga negara Indonesia, tetapi juga bagi pencari suaka ataupun bagi yang telah menjadi pengungsi.

Hukum hak asasi manusia dalam beberapa hal tertentu memiliki korelasi atau hubungan satu sama lain dengan hukum internasional. HAM memuat beberapa prinsip yang universal dan diakui di seluruh negara-negara dalam ranah hukum internasional megenai perlindungan terhadap hak-hak individu atau kelompok. ${ }^{17}$ Esensi hukum hak asasi manusia internasional mengatur kemusiaan tanpa terikat atribut ruang dan waktu. ${ }^{18}$

Hukum internasional telah meletakkan kewajiban dasar bagi tingkah laku negara dalam melaksanakan perlindungan internasionalnya. Tindakan terhadap kewajiban dasar itulah melahirkan sebuah tanggung jawab yang memiliki karakteristik internasional. ${ }^{19}$ Tanggung jawab demikian muncul manakala terdapat pelanggaran terhadap hak-hak asasi manusia "termasuk di dalamnya hak asasi pengungsi"20.

Hukum hak asasi manusia secara umumnya dibagi menjadi beberapa keadaan, pertama, Hukum HAM umum diberlakukan secara normal bagi semua orang dalam keadaan normal. Kedua, hukum HAM diberlakukan dalam situasi

${ }^{16}$ Titon Slamet Kurnia, Interpretasi Hak-Hak Asasi Manusia oleb Mabkamah Konstitusi Republik. Indonesia, The Jimly Court 2003-2008, CV Mandar Maju, Bandung, 2015, hlm. 142.

${ }_{17}$ Wagiman, Op. Cit., hlm. 26.

${ }^{18}$ Agus Fadillah, Pengantar Hukum Internasional dan Hukum Humaniter Internasional, Elsam, Jakarta, 2007, hlm. vi.

${ }^{19}$ Ibid., hlm. 26.

${ }^{20}$ Ibid. 
perang, atau lebih dikenal dengan menggunakan istilah "Hukum Humaniter"21. Ketiga, hukum HAM yang diterapkan dalam keadaan khusus, seperti diterapkan bagi pengungsi karena berada di luar negaranya serta tidak ada yang melindungi. ${ }^{22}$

Pembagian dan batasan bidang, jenis dan macam hak asasi manusia dunia mencakup enam kelompok, diantaranya 23: 1. Personal Rights, yang termasuk dalam kelompok ini adalah hak kebebasan untuk bergerak, bepergian, berpindah-pindah tempat, hak kebebasan mengeluarkan atau menyatakan pendapat, hak kebebasan dan aktif di organisasi atau perkumpulan, serta hak kebebasan memeluk, dan menjalankan agama atau keyakinan yang diyakini; 2. Political Rights, tercakup kedalam kelompok ini adalah hak untuk memilih dan memilih dalam suatu pemilihan, hak ikut serta dalam kegiatan pemerintahan, hak membuat dan mendirikan partai politik dan organisasi politik lainnya, serta hak untuk membuat dan mengajukan suatu petisi; 3. Legal Equality Rights, terdapat kedalam kelompok hak ini melingkupi hak mendapatkan perlakuan yang sama dalam hukum dan pemerintahan, hak untuk menjadi pegawai negeri sipil, serta hak mendapat pelayanan dan perlindungan hukum; 4. Property Rights, hak-hak tersebut seperti hak melakukan kegiatan jual beli, hak kebebasan mengadakan perjanjian kontrak, hak kebebasan menyelengarakan sewa-menyewa, utang piutang, hak kebebasan memiliki sesuatu, serta hak memiliki dan mendapatkan pekerjaan yang layak; 5 . Procedural Rights, hak-hak tersebut seperti mendapatkan pembelaan hukum di pengadilan, hak persamaan atas perlakuan penggeladahan, penangkapan, penahanan dan penyelidikan di mata hukum; 6. Social Culture Rights, hak tersebut mencakup hak menentukan, memilih dan mendapatkan pendidikan, hak mendapatkan pengajaran, serta hak untuk mengembangkan budaya sesua dengan bakat dan minat.

Secara substansial yang secara khusus melindungi hak asasi manusia pada pengungsi adalah termuat dalam konvensi 1951 beserta protokolnya 1967. Dengan

${ }^{21}$ Lihat dalam Rina Rusman, Hukum Humaniter Internasional dalam Studi Hubungan Internasional, RajaGrafindo Persada, Depok, 2013, hlm. 22. "Hukum Humaniter Internasional (HHI), merupakan salah satu alat dan cara yang dapat digunakan oleh setiap negara, termasuk oleh negara damai atau negara netral, untuk ikut serta mengurangi penderitaan yang dialami oleh masyarakat akibat perang yang terjadi diberbagai negara. Dalam hal ini HHI merupakan suatu instrument kebijakan dan sekaligus pedoman teknis yang dapat digunakan oleh semua aktor internasional untuk mengatasi isu internasional berkaitan dengan kerugian dan korban perang".

22 Wagiman, Op. Cit., hlm. 32.

${ }^{23}$ Ibid., hlm. 30-31. 
demikian konvensi tersebut dikategorikan sebagai jenis-jenis hak asasi manusia yang perlu dilindungi, yang secara khusus bagi hak asasi manusia pengungsi dalam ranah hukum internasional.

Terdapat empat prinsip yang harus dijalankan negara terhadap pengungsi, diantaranya adalah: 1. Larangan memulangkan ke negara asalnya (prohibition egainst explusion or return) jika terjadi pemulangan, maka negara dianggap melanggar Pasal 32 dan 33 konvensi pengungsi 1951; 2. Negara tujuan atau negara transit harus dapat memberikan perlindungan khusus dapat memberikan perlindungan keamanan (security of refugees); 3 . Negara tujuan atau negara transit tidak boleh menangkap pengungsi (prohibition against detention of refugees). Penangkapan yang pengungsi yang ada dalam kamp oleh negara tujuan atau negara transit melanggar Pasal 31 Konvensi Pengungsi; 4. Pengakuan dan pemberian status (gainful employment of refugees). Bahwa pemberian kepada pengungsi hanyalah merupakan tahap awal agar pengungsi mendapatkan hakhaknya.

\section{Perlindungan Pengungsi Anak dalam Hukum Internasional}

Perhatian terhadap anak secara umum telah dimulai dengan ditandainya adanya sidang umum perserikatan bangsa-bangsa pada tanggal 20 November 1959 yang mengesahkan "Deklarasi tentang Hak-Hak Anak"24.

Peter Newel mengemukakan beberapa alasan subjektif dari sisi keberadaan anak, sehingga anak membutuhkan perlindungan, antara lain25: 1. Biaya pemulihan (recovery) akibat kegagalan dalam memberikan perlindungan anak sangat tinggi. Jauh lebih tinggi daripada biaya yang dikeluarkan jika anak-anak memperoleh perlindungan; 2. Anak-anak sangat berpengaruh langsung dan berjangka panjang atas perbuatan (action) ataupun tidak adanya/dilakukannya perbuatan (unaction) dari pemerintah dan kelompok lainnya; 3. Anak-anak selalu mengalami pemisahan atau kesenjangan dalam pemberian pelayanan publik; 4. Anak-anak mempunyai hak suara, dan tidak mempunyai kekuatan lobi untuk

${ }^{24}$ Declaration of the rights of the child (proclaimed by general assembly resolution 1386(xiv) of 20 November 1959. This was the basis of the basis of the convention of the rights of the child adopted by the un general assembly 30 years later on 20 November 1989.

${ }^{25}$ M. Nasir Djamali, Anak Bukan Untuk Dibukum (Catatan Pembahasan UU Sistem Peradilan Pidana Anak), Sinar Grafika, Jakarta, 2013, Op. Cit., hlm. 25-26 
memengaruhi agenda kebijakan pemerintah; 5. Anak-anak pada banyak keadaan tidak dapat mengakses perlindungan dan penataan hak-hak anak; dan 6. Anakanak lebih beresiko dalam eksploitasi dan penyalahgunaan akan suatu hal yang dilarang oleh regulasi.

Apabila merunut ke belakang, salah satu prinsip yang harus menjadi perhatian lebih untuk anak adalah best interest of the child ini yang pertama dikemukakan dalam deklarasi diatas yang menurut Lord Mc Dermont, "paramountcy means more than that child's welfare is to be treated as the top item in a list of terms relevan to be matter in question...". ${ }^{26}$ Dengan demikian, kepentingan kesejahteran anak adalah tujuan dan penikmat utama dalam setiap tindakan, kebijakan, dan atau hukum yang dibuat oleh lembaga yang berwenang.

Kedatangan pengungsi pada suatu wilayah negara tertentu tidak hanya menimbulkan permasalahan bagi pengungsi tersebut secara pribadi, tetapi pengungsi terkadang datang membawa sanak keluarga. Sanak keluarga yang dibawa tidak hanya yang berumur telah dewasa, tetapi juga ada yang berumur masih dalam kategori anak-anak. ${ }^{27}$

Dalam keadaan darurat pengungsi, anak-anak pengungsi (pengungsi anak) mudah terpisah dari keluarganya. Maka, upaya registrasi dan penelusuran harus segera dilembagakan. Anak-anak yang terpisah menghadapi resiko lebih besar daripada orang dewasa yang terpisah dengan keluarganya. Karena anak mempunyai kebutuhan perkembangan normal dari anak yang sedang tumbuh dalam kehidupannya. ${ }^{28}$ Anak-anak yang menjadi pengungsi mendapatkan perhatian khusus dalam konvensi hak anak, yaitu dalam Pasal 2229, yang

${ }^{26}$ Savitri Goonesekere, Children, Law and Justice a South Asian Perspective, UNICEF, New Delhi, 1998, hlm. 114.

${ }^{27}$ UNHCR, Refugee Children: Guidelines on Protection and Care, UNHCR, Geneva, 1994, hlm. 12

${ }^{28}$ UNHCR, Perlindungan Pengungsi, Buku Petunjuk Hukum Pengungsi Internasional, UNHCR, Jakarta, 2001, hlm. 77.

29 article (1) "States Parties shall take appropriate measures to ensure that a child who is seeking refugee status or who is considered a refugee in accordance with applicable international or domestic law and procedures shall, whether unaccompanied or accompanied by his or her parents or by any other person, receive appropriate protection and humanitarian assistance in the enjoyment of applicable rights set forth in the present Convention and in other international buman rights or humanitarian instruments to which the said States are Parties". (Negara-negara Pihak harus mengambil langkah-langkah yang tepat untuk menjamin bahwa seorang anak yang sedang mencari status pengungsi atau yang dianggap sebagai pengungsi, sesuai dengan hukum dan prosedur internasional atau domestik yang berlaku, apakah tidak diikuti atau diikuti oleh orang tuanya atau oleh orang lain mana pun, harus menerima perrlindungan yang tepat dan bantuan kemanusiaan dalam perrolehan hak-hak yang berlaku yang dinyatakan dalam Konvensi ini dan dalam instrumen-instrumen hak-hak asasi manusia atau kemanusiaan internasional yang lain, di mana Negara-negara tersebut merupakan pesertanya.) 
mensyaratkan negara memberlakukan untuk mengambil tindakan guna menjamin bahwa anak tersebut menerima perlindungan yang pantas dan bantuan kemanusiaan. Bahkan negara juga diminta menjamin institusi-institusi pelayanan dan fasilitas yang diberikan tanggung jawab untuk kepedulian pada anak atau perlindungan anak yang sesuai dengan standar yang dibangun oleh lembaga anak yang berkompeten, hal ini termaktub dalam Pasal 3 ayat (3) 3$)^{30}$ Konvensi hak Anak.

\section{Tanggung Jawab Indonesia terhadap Pengungsi Anak Menurut Hukum Internasional}

Sejak 1979 Indonesia telah menerima arus pengungsi, ketika ratusan ribu pencari suaka dari Vietnam tiba dengan perahu dan ditempatkan di Pulau Galang sebelum mereka dipindahkan atau dipulangkan ke negara asal mereka. ${ }^{31}$ Selama sepuluh tahun terakhir, Indonesia telah menjadi titik transit utama bagi para pencari suaka yang mencoba untuk pergi ke Australia, akibatnya Indonesia memandang dirinya sebagai "korban" dalam hal arus ilegal para pencari suaka dan pengungsi yang melalui wilayah Indonesia.

Indonesia belum menjadi Negara Pihak dari Konvensi 1951 tentang Status Pengungsi dan Protokol 1967, dan belum memiliki sebuah sistem penentuan status pengungsi. Dengan demikian, pemerintah memberikan kewenangan kepada UNHCR untuk menjalankan mandat perlindungan pengungsi dan untuk menangani permasalahan pengungsi di Indonesia.

Article (2) "For this purpose, States Parties shall provide, as they consider appropriate, co-operation in any efforts by the United Nations and other competent intergovernmental organizations or non-governmental organizations co-operating with the United Nations to protect and assist such a child and to trace the parents or other members of the family of any refugee child in order to obtain information necessary for reunification with his or her family. In cases where no parents or other members of the family can be found, the child shall be accorded the same protection as any other child permanently or temporarily deprived of his or her family environment for any reason, as set forth in the present Convention". (Untuk tujuan ini, maka Negara-negara Pihak harus menyediakan, seperti yang mereka anggap tepat, kerja sama dalam usaha apa pun oleh Perserikatan Bangsa-Bangsa dan organisasiorganisasi antar pemerintah lain yang berwenang, atau organisasi-organisasi non-pemerintah, yang bekerja sama dengan Perserikatan Bangsa- Bangsa untuk melindungi dan membantu seorang anak semacam itu dan melacak setiap orang tua atau anggota-anggota keluarga yang lain dari pengungsi anak, agar dapat memperoleh informasi yang diperlukan untuk melaksanakan repatriasi dengan keluarganya. Dalam kasus apabila orang tua atau para anggota keluarga lainnya sama sekali tidak dapat ditemukan, maka anak itu harus diberi perlindungan yang sama seperti anak yang lainnya, yang secara tetap atau sementara dicabut dari lingkungan keluarganya, karena alasan apa pun, seperti yang dinyatakan dalam Konvensi ini).

30 "States Parties shall ensure that the institutions, services and facilities responsible for the care or protection of children shall conform with the standards established by competent authorities, particularly in the areas of safety, health, in the number and suitability of their staff, as well as competent supervision". (Negara-negara Pihak harus menjamin bahwa berbagai lembaga, pelayanan, dan fasilitas yang bertanggung jawab atas perawatan dan perlindungan tentang anak, harus menyesuaikan diri dengan standar-standar yang ditentukan oleh para penguasa yang berwenang, terutama di bidang keselamatan, kesehatan, dalam jumlah dan kesesuaian staf, mereka dan juga pengawasan yang berwenang).

${ }^{31}$ Suaka, Op. Cit. 
Pengungsi, yang transit atau tinggal sementara di Indonesia, datang dari seluruh penjuru dunia. Sejak 2008, tindakan penganiayaan dan meningkatnya kekerasan yang terus menerus di negara asal mereka, serta keterbatasan ketersediaan negara-negara lain dalam menawarkan solusi permanen, telah mengakibatkan peningkatan jumlah pencari suaka dan pengungsi yang signifikan di Indonesia. Diperkirakan pada 2008 hanya ada 400 pencari suaka dan pengungsi di Indonesia; namun pada bulan Mei 2015, UNHCR melaporkan ada lebih dari 13.000 pencari suaka dan pengungsi yang terdaftar di Indonesia ${ }^{32}$.

Indonesia mengakui hak-hak anak secara universal sesuai dengan Deklarasi Hak-hak anak dan Konvensi hak anak, karena merupakan bagian integral dalam intrumen internasional tentang hak asasi manusia, sehingga meratifikasi Konvensi hak-hak Anak kedalam Keputusan Presiden Nomor 26 Tahun 1990, Maka secara langsung Indonesia telah menyutujui seluruh isi konvensi dalam segala tindakan terhadap anak yang ada di Indonesia seperti yang dijelaskan dalam Pasal 3 ayat (2) ${ }^{33}$ Konvensi hak-hak anak yaitu kewajiban negara untuk melindungi anak yang berada dalam yurisdiksinya.

Indonesia sebagai negara yang berdaulat diberikan wewenang untuk mengatur dirinya tanpa campur tangan negara lain, seperti yang dikatakan oleh Maria Gavounelli bahwa negara dalam perkembangannya mempertahankan sovereignty atas segala tindakan dalam negaranya sehingga negara bebas akan bertindak sesuai dengan kaidah hukum internasional yang telah menjadi kesepakatan bersama.

Di dalam Konvensi Hak Anak telah ditentukan secara khusus mengenai hak-hak anak yang harus diusahakan dan dijalankan oleh semua pihak, tak terkecuali untuk negara. Konvensi ini juga mengatur secara khusus mengenai penanganan pengungsi anak apabila terjadi di dalam negara pihak konvensi, tetapi kenyataannya indonesia tidak menjadi pihak dalam konvensi pengungsi 1951 dan

${ }^{32}$ Ibid.

33 "States Parties undertake to ensure the child such protection and care as is necessary for his or her well-being, taking into account the rights and duties of his or her parents, legal guardians, or other individuals legally responsible for him or her, and, to this end, shall take all appropriate legislative and administrative measures." (Negara-negara Pihak berusaha menjamin perlindungan dan perawatan anak-anak seperti yang diperlukan untuk kesejahteraannya, dengan memperhatikan hak-hak dan kewajiban-kewajiban orang tuanya, wali hukumnya atau orang-orang lain yang secara sah atas dia, dan untuk tujuan ini, harus mengambil semua tindakan legislatif dan administratif yang tepat). 
protokol 1976, sehingga terjadi kekosongan hukum dalam menjalankan perlindungan hukum terhadap pengungsi Anak.

Sebagai negara transit dan bukan negara pihak dalam konvensi 1951 dan protokol 1976, Indonesia tidak mempunyai dasar agar dapat dimintai tanggung jawab yang bersifat leterlijk baik dalam aturan internasional maupun dalam regulasi nasional, sehingga dapat dikatakan "Indonesia relatif tidak banyak terlibat dalam penanganan masalah pengungsi dan menyerahkan penanganan pengungsi pada UNHCR"34.

Walaupun Indonesia hanya sebagai negara transit dan bukan negara pihak dalam konvensi 1951 dan protokol 1967, harus dapat memihak dan memilih posisi dalam menjalankan tanggung jawab sebagai negara yang telah terikat dalam konvensi hak anak, untuk memberikan pelayanan dan perlindungan akan hak-hak anak seperti yang tercantum dalam konvensi tesebut.

Maka pelaksanaan perlindungan pada pengungsi anak dapat dijalankan dengan berdasarkan konvensi hak anak yang memberikan tanggungjawab indonesia sebagai entitas negara dalam internasional yaitu dengan memberikan penjaminan akan tepenuhinya hak-hak anak yang berada dalam yurisdiksi negara dengan cara mengaplikasikan teori oleh Satjipto Rahardjo yang pada intinya negara melindungi dengan cara mengayomi hak-hak seluruh lapisan masyarakat tanpa memandang strata sosial dalam kehidupan bermasyarakat.

Indonesia sebagai negara pihak dalam konvensi hak-hak anak mempunyai tanggung jawab dalam ranah hukum internasional. Karena negara memiliki kedaulatan dalam memberikan perlindungan terhadap pengungsi anak yaitu dengan memberikan jaminan perlindungan hak-hak pengungsi anak sesuai dengan Konvensi hak-hak anak yaitu sesuai dengan Pasal 22 Konvensi Hak Anak secara khusus menyebutkan tentang perlindungan bagi anak yang menjadi pengungsi, walaupun Indonesia belum menjadi pihak Konvensi Pengungsi, tetapi sebagai negara yang menjadi titik transit untuk pengungsi ke tujuan selanjutnya dapat dijalankan agar hak-hak pengungsi anak dapat terpenuhi selama dalam yurisdiksi Indonesia.

\footnotetext{
${ }^{34}$ Sri Badini Amidjojo, Perlindungan Hukum terhadap Pengungsi Berdasarkan Konvensi Jenewa 1951, Badan Pembinaan Hukum Nasional Departemen Hukum dan HAM RI, Jakarta, 2004, hlm. 38.
} 
Adapun Indonesia sebagai subjek dalam hukum internasional mempunyai tanggung jawab terhadap pengungsi anak berdasar pada salah satu general principles recognized civilized nations yaitu jus cogens yang mana mengisyaratkan bahwa setiap tindakan bangsa dalam menjalankan kewajibannya harus melalukan perlindungan akan kemanusiaan dalam ranah perlindungan hak asasi manusia yang dalam hal ini adalah melakukan perlindungan hak-hak asasi pengungsi anak.

Selanjutnya Indonesia juga mempunyai tanggung jawab terhadap perlindungan pengungsi anak, diantaranya dalam international customary law yaitu dengan diakuinya bahwa hukum hak asasi manusia merupakan bagian dari hukum kebiasaan Internasional, maka Indonesia dapat menjadikan salah hal tersebut sebagai satu rujukan untuk memberikan perlindungan kepada pengungsi anak, mengingat negara-negara lain telah menganggap hal tersebut sebagai bentuk perlindungan terhadap nilai-nilai kemanusiaan yang secara khusus diatur dalam konvensi hak-hak anak.

\section{Pengaturan Tanggung Jawab Indonesia bagi Pengungsi Anak Menurut Hukum Nasional di Masa yang akan Datang}

Indonesia merupakan salah satu negara yang belum meratifikasi Konvensi 1951 dan Protokol 1967, karena adanya kekhawatiran akan timbulnya kewajiban negara untuk menerima pengungsi bermukim tetap di Indonesia, serta adanya ketakutan bahwa Indonesia akan kebanjiran oleh pengungsi dari berbagai negara. ${ }^{35}$ Kedua alasan ini perlu ditinjau ulang mengingat pada kenyataannya ada beberpa faktor yang menyebabkan dibanjiri atau tidaknya suatu negara oleh pengungsi antara lain kedekatan geografis dan budaya serta jaminan kehidupan di masa depan.

Beberapa negara yang dapat dijadikan contoh telah meratifikasi Konvensi Pengungsi 1951 adalah Filipina ${ }^{36}$ dan Timor Leste ${ }^{37}$, tetapi dalam kenyataannya

${ }^{35}$ Sri Badini Amidjojo, Op. Cit., hlm. 45.

${ }^{36}$ Filipina melakukan telah melakukan ratifikasi Konvensi 1951 beserta Protokolnya pada 22Juli1981,:https:// treaties.un.org/pages/ViewDetailsII.aspx?src=TREATY\&mtdsg_no=V2\&chapter=5\&Tem $\mathrm{p}=$ mtdsg2\&lang $=$ en, diakses tanggal 18 Maret 2016.

${ }^{37}$ Timor Leste melakukan telah melakukan ratifikasi Konvensi 1951 beserta Protokolnya pada tanggal 7 Mei 2003, berdasarkan pada :

https:/ /treaties.un.org/pages/ViewDetailsII.aspx?src $=$ TREATY\&mtdsg_no $=V-2 \& c h a p t e r=5 \& T e m p=$ mtdsg2\&lang=en , diakses tanggal 18 Maret 2016 
tidak ada pengungsi yang menetap di negara tersebut. Indonesia bila dilihat dalam ranah geografis berada pada jalur lintas pengungsi yang akan menuju Australia. Dengan adanya kenyataan ini maka akan tetap banyak pengungsi yang terdapat di Indonesia bukan karena keterkaitan pengungsi dengan Indonesia. ${ }^{38}$ Dengan demikian posisi indonesia sebagai penandatangan atau tidak, akan tetap dianggap sebagai negara transit maupun tempat singgah atau terdamparnya calon pengungsi yang telah melakukan perjalanan menuju negara tujuan.

Dilihat dari substansinya, konvensi pengungsi ini pada dasarnya tidak membebani kewajiban negara untuk meratifikasinya. Tetapi atas dasar pertimbangan nilai-nilai kemanusiaan yang diderita oleh para pengungsi, sehingga hal tersebut yang menjadikan alasan mendominasi agar dapat teratifikasinya konvensi ini. Perlindungan terhadap pengungsi merupakan bagian dari perlindungan terhadap hak asasi manusia, "yang secara khusus terhadap manusia bebas yang terpaksa melarikan diri dari negara karena kondisi yang mengancam pelaksanaan haknya sebagai manusia" 39 .

Pemajuan dan perlindungan hak asasi manusia merupakan salah satu kewajiban pemerintah suatu negara terhadap warga negaranya dan penduduk yang berada di wilayah yurisdiksinya dalam rangka mewujudkan suatu masyarakat yang aman, sejahteram dan bebas dari rasa takut dan kekurangan. ${ }^{40}$ Walaupun kewajiban suatu negara sesungguhnya adalah untuk meningkatkan kesejahteraan warga negaranya, namun hal ini tidak berarti bahwa negara yang bersangkutan boleh menutup mata apabila di wilayah tinggalnya tinggal orangorang asing yang terusir dari negaranya dan menderita karena statusnya sebagai pengungsi.

Perlindungan terhadap hak asasi manusia dalam pengungsi juga merujuk secara langsung kepada penerus generasi masa depan selanjutnya, yaitu perlindungan terhdap hak-hak pengungsi anak. Sebagai negara yang telah meratifikasi konvensi yang secara khusus mengatur tentang Hak Anak yaitu

${ }^{38}$ Sri Badini Amidjojo, Op. Cit., hlm. 44.

${ }^{39}$ Ibid., hlm. 46.

${ }^{40}$ Titon Slamet Kurnia, Op. Cit., hlm. 108. 
Konvensi Anak-Anak 1990, maka sejak 1990 tersebut Indonesia terikat secara hukum Internasional untuk melaksanakan ketentuan dalam konvensi tersebut.

Menurut Erna Sofyan Syukrie ${ }^{41}$, negara-negara pihak yang telah meratifikasi konvensi hak anak menerapkan beberapa hal dalam sistem hukumnya, yaitu: 1 . Memeriksa dan menelaah terhadap peraturan perundang-undangan yang telah disahkan dan masih dalam proses perancangan yang dalam hal ini ada kaitannya dengan anak; 2. Mengevaluasi lembaga-lembaga negara yang ada hubungannya dengan pelaksanaan konvensi hak anak; 3. Menyususn langkah-langkah harmonisasi ketentuan dalam konvensi hak anak dengan peraturan perundangundangan yang ada di Indonesia; 4 . Meninjau ulang bagian peraturan perundangundangan yang masih berlaku tetapi membutuhkan penyempurnaan agar tepat sasaran dan tujuan sesuai dengan yang dijabarkan dalam konvensi hak anak; 5. Memprioritaskan acara pembuatan undang-undang yang diperlukan untuk mengefektifkan pelaksanaan konvensi hak anak, sehingga akan terciptanya penyelaralasan antara konvensi hak anak dengan peraturan perundang-undangan di Indonesia; 6. Mencari dan menganalisis perjanjian-perjanjian internasional yang ada kaitannya dengan hak-hak anak, supaya mempermudah perlindungan akan hak-hak anak sesuai dengan kaidah-kaidah internasional yang lebih baru dan dapat diratifikasi oleh Indonesia.

Dalam ranah regional ASEAN, beberapa negara telah meratifikasi Konvensi Pengungsi 1951. Selanjutnya pada 31 Agustus 1987, Filipina telah membuat Executive Order No 304 on Authorizing The Task Force On Refugee Assistance And Administration And The Department Of Foreign Affairs To Respectively Issue Identity Papers And Travel Documents To Refugees Staying In The Philippines And Prescribing Guidelines Therefor sebagai bentuk tindak lanjut dari diratifikasinya konvensi pengungsi yang isinya memuat 5 section yang secara garis besar berisi: 1 . Section 1 : memberikan identitas resmi yang khusus kepada pengungsi, sebagai upaya perlindungan dan pencatatan identitas dari pemerintah Filipina; 2. Section 2 : memberikan peluang kepada pengungsi apabila berkebutuhan untuk bepergian keluar wilayah filipina, tetapi sesuai dengan aturan yang di atur oleh the Task Force

${ }^{41}$ M. Nasir Djamil, Op. Cit., hlm. 13. 
on Refugee Assistance and Administration (TFRAA); 3. Section 3 : tidak diperbolehkan adanya dokumen bepergian ke luar wilayah Filipina tanpa rekomendasi dari TFRAA dan melengkapi syarat-syarat sesuai dengan yang ditetapkan oleh Department of Foreign Affairs (DFA); 4. Section 4 : bahwa dokumen bepergian dibuat sama dengan yang ditentukan dalam konvensi pengungsi 1951; 5. Section 5 : bahwa aturan ini diberlakukan dalam waktu yang sesegera mungkin.

Selanjutnya Filipina telah mempunyai kesepakatan dengan UNHCR dalam melaksanakan program-program dalam melindungi pengungsi yaitu dengan dibuatnya Country Operations Plan 2014 yang pada substansinya mempromosikan dan memantau pelaksanaan Konvensi Pengungsi 1951. Filipina adalah salah satu negara di Asia Tenggara yang merupakan Konvensi Penandatangan dan memiliki sistem perlindungan pengungsi yang dilembagakan. UNHCR akan terus mempromosikan berlakunya peraturan hukum yang selanjutnya dapat mengubah dan merevisi undang-undang nasional tentang imigrasi, sebagai tindak lanjut mengakui hak-hak pengungsi sebagaimana diatur dalam Konvensi.

Adapun dalam Country Operations Plan 2014 juga memuat beberapa tujuan diantaranya ${ }^{42}$ :

"Philippine Immigration law amended to incorporate provisions recognizing rights of refugees and asylum seekers under the 1951 Refugee Convention; 1954 Convention on Statelessness is ratified by the Philippine Senate; Training for DOJ (department of justice)-Refugee Processing Unit and immigration officials provided; RSD (refugee status determination) process supported by UNHCR in observer or advisory capacity; Entitlement of refugees to work permits, regularization of immigration status ensured; Refugees are granted permanent residence or are naturalized; UNHCR promotional and advocacy objectives are included in efforts of various stakeholders; and Government contingency plans describing possible scenarios and identifying resources required for a response are facilitated by support for Emergency Management and Contingency Planning initiatives"

Upaya-upaya perlindungan hak-hak di Indonesia masih sangat terbatas pada ranah anak yang membutuhkan perlindungan khusus seperti yang tertulis dalam Pasal $59^{43}$ Undang-Undang Nomor 23 Tahun 2002 bahwa negara wajib

\footnotetext{
42UNHCR, Country Operations Plan year 2004 on Philipines, UNHCR : 2004.

${ }^{43}$ Pasal 59 "Pemerintah dan lembaga negara lainnya berkewajiban dan bertanggung jawab untuk memberikan perlindungan khusus kepada anak dalam situasi darurat, anak yang berhadapan dengan hukum, anak dari kelompok minoritas dan terisolasi, anak tereksploitasi secara ekonomi dan/atau seksual, anak yang diperdagangkan, anak yang menjadi korban penyalahgunaan narkotika, alkohol, psikotropika, dan zat adiktif
} 
memberikan perlindungan khusus kepada anak-anak dengan berbagai kategorinya, salah satunya adalah anak yang berada dalam kondisi darurat. Diperjelas dalam Pasal $60^{44}$ poin a adalah anak yang menjadi pengungsi, tetapi hingga saat ini Indonesia belum mempunyai instrumen hukum yang sifatnya tertulis dalam melindungi hak-hak anak yang memerlukan perlindungan khusus sebagai pengungsi karena Indonesia tidak menjadi negara pihak dalam konvensi pengungsi 1951.

Adapun dengan merujuk teori Yurisdiksi menurut Imre Anthoni yang mengemukakan bahwa yurisdiksi negara dalam hukum internasional publik berarti hak dari suatu negara untuk mengatur dan memengaruhi dengan langkahlangkah atau tindakan yang bersifat legislatif, eksekutif atau yudikatif atas hak-hak individu, milik atau harta kekayaannya, prilaku-prilaku atau peristiwa-peristiwa yang tidak semata-mata merupakan masalah dalam negeri. ${ }^{45}$ Indonesia mempunyai yurisdiksi untuk mengatur urusan apapun dalam negeri karena yurisdiksi merupakan refleksi dari prinsip dasar kedaulatan negara.

Selanjutnya dengan memperhatikan teori tanggung jawab negara sebagai entitas dalam hukum internasional harus dapat menjalankan dan melaksanakan segala kesepakatan atau persetujuan dalam hukum internasional, sehingga menurut Malcolm N. Shaw, Indonesia tidak dianggap sebagai negara yang tidak bertanggung jawab terhadap hal-hal yang diatur dalam nilai-nilai universal dalam hukum internasional dan prinsip dasar dalam memberikan perlindungan hukum sebagai negara. Menurut Fitzgerald untuk kepentingan hukum, karena kepentingan hukum adalah mengurusi hak dan kepentingan manusia, sehingga hukum memiliki otoritas tertinggi untuk menentukan kepentingan manusia agar perlu diatur dan dilindungi.

Hukum bertugas menjamin kepastian hukum di dalam masyarakat dan juga menjaga serta mencegah agar setiap orang tidak menjadi hakim sendiri. adanya potensi terjadinya antara kebutuhan masyarakat dalam melindungi pengungsi dan

\footnotetext{
lainnya (napza), anak korban penculikan, penjualan dan perdagangan, anak korban kekerasan baik fisik dan/atau mental, anak yang menyandang cacat, dan anak korban perlakuan salah dan penelantaran”.

${ }^{44}$ Pasal 60 "Anak dalam situasi darurat sebagaimana dimaksud dalam Pasal 59 terdiri atas : a. anak yang menjadi pengungsi; b. anak korban kerusuhan; c. anak korban bencana alam; dan d. anak dalam situasi konflik bersenjata".

${ }^{45}$ Sefriani, Hukum Internasional Suatu Pengantar, RajaGrafindo Persada, Jakarta, 2014, hlm. 233.
} 
tidak adanya aturan yang jelas mengenai pengaturan hal tersebut. Pada dasarnya masyarakat tidak dapat menunggu adanya persesuaian antara kedua hal tersebut. ${ }^{46} \mathrm{Hal}$ ini disebabkan adanya kebutuhan untuk memenuhi kekaburan dalam pengaturan untuk pengungsi anak. Dengan demikian munculah tuntutan yang lebih praktis sifatnya, yaitu keharusan adanya aturan sehingga tercipta kepastian hukum dalam melindungi hak-hak anak pada pengungsi anak.

Sebagai negara yang mempunyai tanggung jawab akan perlindungan anak. Maka Indonesia harus membuat prioritas untuk segera meratifikasi konvensi tersebut. Akan ada harmonisasi pemahaman dari beberapa hak yang diberikan secara khusus pada anak dalam konvensi hak anak dengan konvensi pengungsi 1951.

Selanjutnya dengan telah meratifikasi konvensi pengungsi 1951 beserta protokolnya, maka selanjutnya adalah memahami harmonisasi hak-hak yang melingkupi perlindungan khusus bagi pengungsi anak, Indonesia harus membuat peraturan perundang-undangan turunan dari konvensi tersebut, mengingat sifat dari ratifikasi sebuah perjanjian internasional bukan merupakan applicable regulation. Sehingga akan ada peraturan perundang-undangan yang secara khusus membahas tentang penanganan dan perlindungan pengungsi anak di Indonesia, dengan merujuk pada konvensi status pengungsi dan konvensi hak-hak anak.

\section{Penutup}

Berdasarkan uraian di atas, dapat disimpulkan bahwa: pertama, Indonesia tidak memiliki tanggung jawab yang bersifat leterlijk sebagai negara transit terhadap perlindungan pengungsi anak menurut hukum internasional karena Indonesia hingga saat ini tidak menjadi negara pihak dalam Konvensi Pengungsi 1951 dan Protokolnya 1967, akan tetapi sebagai negara pihak dalam konvensi hakhak anak Indonesia memiliki tanggung jawab terhadap pengungsi anak sesuai dengan Pasal 22 konvensi hak-hak anak, serta menurut hukum kebiasaan internasional bahwa negara melakukan perlindungan akan prinsip hak asasi

${ }^{46}$ Jazim Hamidi dan Charles Christian, Hukum Keimigrasian Bagi Orang Asing di Indonesia, Sinar Grafika, Jakarta, 2015, hlm. 30 . 
manusia yang secara tidak langsung juga mewajibkan untuk melindungi hak-hak pengungsi anak, dan dalam prinsip hukum yaitu jus cogens yang pada substansinya melindungi hukum dalam ranah kemanusiaan. Selanjutnya hukum pengungsi dan hak-hak anak merupakan bagian dari hak asasi manusia, sehingga Indonesia secara normatif bertanggung jawab dalam perlindungan pengungsi anak berdasarkan prinsip hak asasi manusia. Kedua, dalam rangka mencapai kepastian hukum, maka bentuk tanggung jawab Indonesia bagi pengungsi anak dalam pengaturan hukum nasional di masa yang akan datang adalah dengan meratifikasi konvensi pengungsi 1951 beserta protokol 1967, dan selanjutnya membuat peraturan perundang-undangan. Sehingga akan ada peraturan perundang-undangan yang secara khusus membahas tentang tanggung jawab Indonesia sebagai negara transit dalam memberikan penanganan dan perlindungan pengungsi anak di Indonesia, dengan merujuk pada konvensi status pengungsi dan konvensi hak-hak anak.

\section{Daftar Pustaka}

\section{Buku}

Badini Amidjojo, Sri, Perlindungan Hukum terhadap Pengungsi Berdasarkan Konvensi Jenewa 1951, Badan Pembinaan Hukum Nasional Departemen Hukum dan HAM RI, Jakarta, 2004.

Djamali, M. Nasir, Anak Bukan Untuk Dihukum (Catatan Pembahasan UU Sistem Peradilan Pidana Anak), Sinar Grafika, Jakarta, 2013.

Goonesekere, Savitri, Children, Law and Justice a South Asian Perspective, UNICEF, New Delhi, 1998.

Hamidi, Jazim, dan Charles Christian, Hukum Keimigrasian Bagi Orang Asing di Indonesia, Sinar Grafika, Jakarta, 2015.

Mahmud Marzuki, Peter, Penelitian Hukum, Prenada Media Group, Jakarta, 2014.

Mertokusumo, Sudikno, Penemuan Hukum, Liberty, Yogyakarta, 2004.

Rusman, Rina, Hukum Humaniter Internasional dalam Studi Hubungan Internasional, RajaGrafindo Persada, Jakarta, 2013.

Sefriani, Hukum Internasional Suatu Pengantar, RajaGrafindo Persada, Jakarta, 2014.

Slamet Kurnia, Titon, Interpretasi Hak-Hak Asasi Manusia oleh Mahkamah Konstitusi Republik Indonesia, The Jimly Court 2003-2008, CV Mandar Maju, Bandung, 2014. 
UNHCR, Refugee Children: Guidelines on Protection and Care, UNHCR, Geneva, 1994.

UNHCR, Perlindungan Pengungsi, Buku Petunjuk Hukum Pengungsi Internasional, UNHCR, Jakarta, 2001.

UNHCR, Country Operations Plan year 2004 on Philipines, UNHCR, Geneva, 2004.

Wagiman, Hukum Pengungsi Internasional, Sinar Grafika, Jakarta, 2012.

\section{Hasil Penelitian}

Erdiana, Fita, Perlindungan Hukum Bagi Pengungsi Akibat Konflik Bersenjata di Republik Demokratik Kongo Menurut Hukum Pengungsi Internasional, Tesis, Universitas Sebelas Maret, Surakarta, 2009.

\section{Majalah / Koran}

Save the Children, Protecting Children from Exploitation, http:/www.savethechildren.org.

Septia, Karnia, Menteri Yohana: Indonesia Darurat Kekerasan terhadap Anak, Kompas, 8 Oktober 2015.

Wibisono, Makarim, “Dilema Rohingya”, Majalah DETIK edisi 1-7 Juni 2015.

\section{Internet}

Alif Goenawan, Muhammad, soal Mobilitas, Medsos, Big data dan Cloud, Detik.com, diakses pada tanggal 21 Desember 2015.

Presidential Museum and Library, The Philipines as Haven for Refugee, http:/www.malacanang.gov.ph.

Suaka, Refugees and Asylum Seekers in Indonesia, (http:/www.suaka.or.id)

\section{Peraturan Perundang-undangan}

Undang-Undang Republik Indonesia Nomor 23 Tahun 2002 tentang Perlindungan Anak.

Undang-Undang Republik Indonesia 35 Tahun 2014 tentang Perubahan Atas Undang-Undang Nomor 23 Tahun 2002 tentang Perlindungan Anak. 